\title{
Foreign Workers to Entrepreneurs: A Framework of Job Displacement Model
}

\author{
Norehan Abdullah ${ }^{1}$, Selamah Maamor ${ }^{1}$, Asan Ali Golam Hassan ${ }^{1}$, Hussin Abdullah ${ }^{1}$, Fauzi Hussin ${ }^{1} \&$ Ahmad \\ Zafarullah Abdul Jali1 ${ }^{1}$ \\ ${ }^{1}$ School of Economics, Finance and Banking, College of Business, Universiti Utara Malaysia, Malaysia \\ Correspondence: Norehan Abdullah, School of Economics, Finance and Banking, College of Business, \\ Universiti Utara Malaysia, Kedah, Malaysia. Tel: 60-19-551-5521. E-mail: norehan@uum.edu.my
}

Received: January 30, 2012 Accepted: February 28, 2012 Online Published: May 16, 2012

doi:10.5539/ijbm.v7n10p2

URL: http://dx.doi.org/ijbm.v7n10p2

\begin{abstract}
The entry of foreign workers on a large scale to Malaysia in the 1980s was mainly to smooth and facilitate the development of economic structural change as unskilled labor in the formal sector. It is expected that in the process of adjusting to economic changes, there is a shift of employment of foreign workers, especially during an economic crisis in 1997 and 2008. The main objective of this study was to establish a hypothetical model of job displacement of unskilled foreign labor to entrepreneurs. Data was gathered through a survey on foreign businessmen who once worked as laborers in Malaysia. Descriptive analysis results show that most migrant workers were able to shift into entrepreneurs due to the high desire to try his luck and take advantage of a stable economic situation. Furthermore, those migrants are more likely to become entrepreneurs in the same business sector of the field when first engaged as unskilled workers. Among the driving factors that contributed to the job displacement includes working experience, the existence of opportunity and fellow encouragement
\end{abstract}

Keywords: model of job displacement, foreign workers, migrant- entrepreneurs, driving factors

\section{Introduction}

Immigrant entrepreneurship is an important socio-economic phenomenon of the century. The main destinations of immigrants in the country like the United States, Canada, Britain, and Australia, migrant entrepreneurs play an important role in economic development. Economic impact of migrants in the host country operators is aware, but its influence is not limited to economic aspects alone. It involves important non-economic effects such as the development of ethnic community spirit, social integration and recognition of immigrants, a spirit of entrepreneurship preserving, and providing a role model for immigrants (Chrysostome \& Lin, 2010), especially for unskilled workers resulting in increased entry of foreign labor.

The phenomenon of entrepreneurship among immigrants was also warm in Malaysia. Although the planned economy towards knowledge-based economy when reaches full employment level in 2005, with the unemployment rate of $3.5 \%$, but the number of foreign workers continues to grow. In the same year, there were approximately 1.7 million foreign workers (with work permit) in Malaysia (Malaysia, 2006). Number of non-citizen population (working age) increased dramatically from 215 thousand in 1982 to 1.2 million people in 2005. While not a citizen of the labor force increased from 138 thousand to 1.03 million in the same period.

As a result of the economic crisis, migrant workers who had been working as a laborer in Malaysia lost their jobs. However, most of them refused to return to their original country and decided to remain in Malaysia. Hence, these foreign migrants find their way to search for work intended to cover the cost of their lives in this country. When the transformation is said to be, there are numbers of the existence of labor migrants from foreign migrants. Many entrepreneurs who start their own businesses intended to cover the cost of living and their families. Various business activities are conducted with a total capital they have. Among the business conducted by foreign migrants are a food stall business and other businesses.

The success of their own business is also assisted by the local people. The locals who are willing to partner with them and hire shops for foreign migrants somehow give them opportunities to start a business. Thanks to the efforts of this migrant entrepreneurs, eventually some of them can establish their own companies, whether small or large scale. There are also foreign workers who have managed to become entrepreneurs took the opportunity to improve their lives doing wrong in the law of this country. Companies may be owned by locals but foreign 
operators who manage most of the way companies operation and their employees who are employed are foreign workers. In addition, the existence of Bumiputera entrepreneurs in competition with foreign producers that are not registered for offering much lower prices than the competition, especially Bumiputera entrepreneurs to sub-contract work. Of course people will choose foreign operators because the price offered is far cheaper. The question is how they can start a business and who are the main drivers for them to start a business in Malaysia? What is the driving factor of their success to succeed? How much monthly income they receive revenue from the businesses they earn? This paper seeks to develop a framework of foreign labor employment shifts to the entrepreneurs.

\section{Literature Review}

Past studies related to business are widespread. Past studies of the migrants were mainly solving the problem of new migrants in the country, especially the push and pull factors, employment issues, discrimination and acceptance. In Malaysia, there are no specific studies as the study of migrant workers shift to the operators. This may be because the issue is a new phenomenon of concern. However, there are several studies in developed countries are discussing the issue of migrants who shifts to become entrepreneurs.

Contribution of migrant entrepreneurs of the country of destination cannot be denied it. Ayda et. al (2010) concluded that the producers of these migrants contribute to the growth of various products and services, not only because they are skilled and competent, but because of social relations with local communities. In a study of Turkish migrant entrepreneurs in Switzerland, Baycan-Levent \& Kundak (2009) found that the movement of a foreign employee to an entrepreneur is very common and easily among Turkish immigrants. Socio-cultural norms of factors, government policies and the educational system in the host country Switzerland to make people less inclined to become entrepreneurs. Mustafa \& Chen (2010) studied on how five entrepreneurs- can be the internationalization of business and the role of transnational family network. The results showed that the producers of these migrants have access to resources and using the relationship between transnational borders is through family and kinship networks that allow them to simultaneously engage in social and business activities in both countries.

In Malaysia, Asan Ali Golam Hassan (2009) discusses the profile of migrant workers who emigrated to this country have tried to formulate a hypothetical case in respect of employment and the status of environment in which they were originally migrant workers to Malaysia starts from a labor and now has become entrepreneurs. Based on hypothetical cases studied, he found that the foreign workers have shift jobs, and now has become entrepreneurs in Malaysia. It is expected that the involvement of foreign traders will result in a slower efforts to improve the indigenous group in business activity because of the competition between local and foreign entrepreneurs. These findings reinforce the importance of his study.

Fairly and Woodruff (2010) also studied the income gap migrant entrepreneurs with local entrepreneurs Mexico-US. He found that the income gap between migrants and local entrepreneurs was large in which migrant entrepreneurs earn less than the local entrepreneurs. Migrant's entrepreneurs have low levels of education and limited English speaking skills makes it difficult for them to work with local people. Migrant Entrepreneurs in the U.S. has strict barriers to promote their business, especially obstruction of legal, financial and human capital. But this is not a problem for Mexican migrants to start their business there because the cost of their migration to these countries is lower than the cost of migrating to the U.S. or other nations.

\section{Method of Study}

Respondents are foreign workers, unskilled of workers who had come to Malaysia as a laborer and then became entrepreneurs regardless of whether under their own company name or the name of the local people. The study covered the whole area in Malaysia, including Sabah and Sarawak and immigrants, they cover all the categories of workers, entrepreneurs, regardless of any State. Since the actual population of migrant workers-employers is not known, the study used "snowball" sampling method. A total of 82 respondents successfully interviewed and tested descriptive information of cross-tabulation analysis.

\section{Results \& Discussion}

The distribution of the number of migrant entrepreneurs by year of begin trading are illustrated in Figure 1 . The shaded areas are the financial crisis and economic crisis in 1998-2000 and 2008-2009. It was found that most of these workers become entrepreneurs in the years between two of the crisis, in the year 2002 until 2008. 


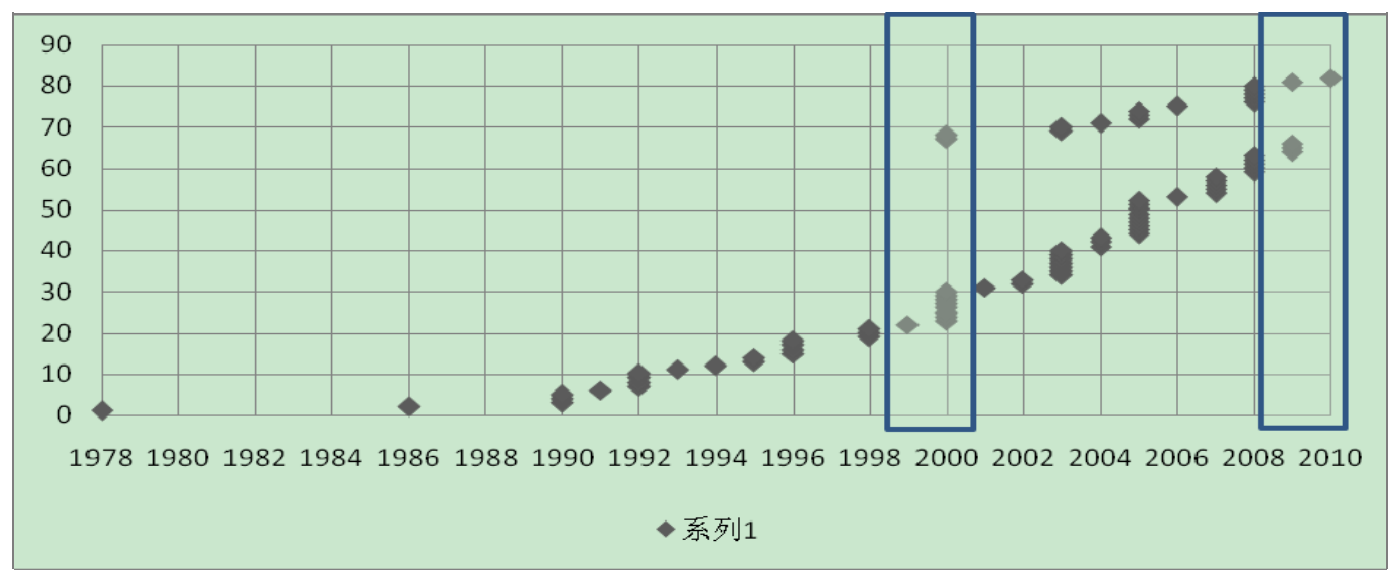

Figure 1. Numbers of Migrant Entrepreneurs 1978-2010

In analyzing profile of respondents, Table 1 shows that male respondent constitute almost 60 percent of respondent. With only 42.7 percent of the sample, the female are well represented in the immigrant entrepreneur community.

Table 1. Characteristics of Respondents

\begin{tabular}{llc}
\hline Variables & & Percent \\
\hline Gender & Male & 57.3 \\
Origin & Female & 42.7 \\
& China & 2.4 \\
& Bangladesh & 4.8 \\
& Myanmar & 3.6 \\
& Filipina & 1.2 \\
& India & 4.8 \\
& Indonesia & 41.4 \\
& Cambodia & 3.6 \\
& Lubnan & 1.2 \\
& Egypt & 1.2 \\
& Pakistan & 3.6 \\
& Thailand & 31.0 \\
Duration of Stay (year) & Vietnam & 1.2 \\
& <10 & 28 \\
& 11 -20 & 37.9 \\
& $21-30$ & 20.7 \\
HighestLevel of & $31-40$ & 9.7 \\
Education & $>40$ & 3.7 \\
& No Schooling & 20.7 \\
& Primary School & 30.5 \\
& Secondary School & 25.6 \\
& Certificates & 11.0 \\
& Degree & 12.2 \\
\hline
\end{tabular}

In term of country of origin, more than 40 percent of our sample originated from Indonesia. The Thais come in second with 31 percent of the sample. Another 13.2 percent of the samples are constituted by immigrant entrepreneurs originating from the Indian subcontinent (India, Pakistan and Bangladesh). Other countries of origin represented in the sample are China (2.4 percent), Myanmar (3.6 percent), Cambodia (3.6 percent), Lebanon (1.2 percent), Egypt (1.2 percent) and Vietnam (1.2 percent). It is noteworthy that 82 percent of immigrant entrepreneurs come from within the South-East Asia region which implies that distance is still a major factor that a migrant will take into consideration in choosing a country to migrate to. However in a globalised 
world where intercontinental travel and communication have become increasingly affordable and easy, it is expected this factor would in the future lose its importance. The table also indicates that almost 60 percent of the immigrant entrepreneurs have stayed in Malaysia for a period of between 11 to 30 years which implies that it takes a relatively long period of time before a migrant can become an entrepreneur.

This paper discusses the results of cross tabulation based on three variables, namely business period, income, and line of business.

i) Business period

Table 2 shows the cross tabulation between the three factors: citizenship status, business line and income by business period. It is found that many migrant businessmen with a total of 1 to 5 years business period have citizenship status of permanent residents. The same is true for those with 6 to 10 years of business period. This is a strong motivating factor for migrant business men when their citizenship status does not violate the laws of the country. Furthermore, migrant entrepreneurs feel more secure doing business with the status.

Table 2. Status of Citizenship, Line of Business, Income and Business Period

\begin{tabular}{|c|c|c|c|c|c|c|}
\hline \multirow[t]{2}{*}{ VARIABLES } & \multicolumn{6}{|c|}{ BUSINESS PERIOD /year (PERCENT) } \\
\hline & $1-5$ & $6-10$ & $11-15$ & $16-20$ & $21-25$ & $>25$ \\
\hline \multicolumn{7}{|l|}{ Status of Citizenship } \\
\hline - Malaysian & 12.2 & 7.4 & 4.9 & 7.4 & 1.2 & 0 \\
\hline - Permanent Resident & 18.3 & 13.4 & 4.9 & 2.4 & 0 & 1.2 \\
\hline - Workers- permit & 11.0 & 8.5 & 1.2 & 2.4 & 0 & 0 \\
\hline - Others & 2.4 & 0 & 1.2 & 0 & 0 & 0 \\
\hline \multicolumn{7}{|l|}{ Line of Business } \\
\hline - Hawkers & 2.4 & 0 & 0 & 0 & 0 & 0 \\
\hline - Food & 1.2 & 0 & 0 & 0 & 0 & 0 \\
\hline - Stall & 7.3 & 3.7 & 0 & 0 & 0 & 0 \\
\hline - Furniture & 0 & 1.2 & 1.2 & 0 & 0 & 0 \\
\hline - Food stall/restaurant & 7.3 & 7.3 & 6.1 & 3.6 & 0 & 0 \\
\hline - Grocery store & 3.7 & 4.9 & 0 & 0 & 0 & 0 \\
\hline \multirow[t]{2}{*}{ - Construction / craftsman house / boat / electric } & 1.2 & 1.2 & 1.2 & 2.4 & 0 & 0 \\
\hline & 13.4 & 7.3 & 3.7 & 6.1 & 0.2 & 1.2 \\
\hline - Clothes shops / salon / decorative & 1.2 & 2.4 & 0 & 0 & 0 & 0 \\
\hline - Electrical / building / agricultural products & 6.1 & 0 & 0 & 0 & 0 & 0 \\
\hline - Motor vehicle workshop & 0 & 1.2 & 0 & 0 & 0 & 0 \\
\hline - Others & 0 & 0 & 0 & 1.2 & 0 & 0 \\
\hline \multicolumn{7}{|l|}{ Income (RM) } \\
\hline$-<1,000$ & 9.8 & 4.9 & 0 & 0 & 0 & 0 \\
\hline$-1,001-5,000$ & 25.6 & 18.3 & 4.9 & 8.5 & 0 & 0 \\
\hline$-\quad 5,001-10,000$ & 4.9 & 6.1 & 6.1 & 2.4 & 0 & 0 \\
\hline$-10,000-15,000$ & 0 & 0 & 1.2 & 1.2 & 1.2 & 1.2 \\
\hline$-\quad 15,000-20,000$ & 3.7 & 0 & 0 & 0 & 0 & 0 \\
\hline
\end{tabular}

In terms of business, respondents who have shifted to be entrepreneurs in the period of 1 to 5 years are heavily involved in business of clothing, salons or decorative items. The second line of business is the food store ventured by migrant businessmen in within the period of 1 to 15 years. Looking at the longest business period of being entrepreneurs, which is more than 25 years, the field of business have also been the clothing stores, salons or decoration. This clearly shows that this line of business is the most sought after and can last for quite some 
time.

In terms of average monthly income earned, this study found that migrant businessmen with 1 to 5 years business period earn income from RM1001 to RM5000. Although they are still new in business but they actually able to reach a slightly higher monthly income than when they were migrant laborers. Similarly, the second highest figures are those who become entrepreneurs within 6 to 10 years. If examined further, the longer the business period, the higher the average monthly income. Hence, migrant entrepreneurs will continue their business effort to reach higher monthly income.

ii) Income

Income is the main goal of a producer or an entrepreneur. Table 3 shows the relationship of business ownership and the country of origin by type of ownership of their business. This study found that those who have the status of the sole owner of the business earn around RM1001 to RM5000 as well as for families who have a business partnership type of ownership.

Table 3. Income by Type of Business Ownership and Origin

\begin{tabular}{|c|c|c|c|c|c|}
\hline \multirow[t]{2}{*}{ VARIABLES } & \multicolumn{5}{|c|}{ INCOME(PERCENT) } \\
\hline & $\begin{array}{c}< \\
\text { RM1,000 }\end{array}$ & $\begin{array}{c}\text { RM1,000- } \\
5,000\end{array}$ & $\begin{array}{c}\text { RM5,001- } \\
10,000\end{array}$ & $\begin{array}{c}\mathrm{RM} 10,000 \\
-15,000\end{array}$ & $\begin{array}{c}\text { RM15,000 } \\
-20,000\end{array}$ \\
\hline \multicolumn{6}{|l|}{ Types of ownership: } \\
\hline -Sole ownership & 7.3 & 31.7 & 11.0 & 3.7 & 2.4 \\
\hline -Family Partnership & 2.4 & 18.3 & 7.3 & 1.2 & 1.2 \\
\hline -Non-family partnership & 4.9 & 7.3 & 1.2 & 0 & 0 \\
\hline \multicolumn{6}{|l|}{ Country of Origin: } \\
\hline - Indonesia & 6.1 & 28.1 & 6.1 & 0 & 1.2 \\
\hline - $\quad$ Thailand & 8.5 & 15.9 & 4.9 & 0 & 1.2 \\
\hline - Myanmar & 0 & 0 & 2.4 & 1.2 & 0 \\
\hline - Kembodia & 0 & 1.2 & 0 & 2.4 & 0 \\
\hline - Filipina & 0 & 1.2 & 0 & 0 & 0 \\
\hline - Vietnam & 0 & 1.2 & 0 & 0 & 0 \\
\hline - $\quad$ Bangladesh & 0 & 3.7 & 1.2 & 0 & 0 \\
\hline - India & 0 & 0 & 4.9 & 0 & 0 \\
\hline - Pakistan & 0 & 3.7 & 0 & 0 & 0 \\
\hline - Lubnan & 0 & 0 & 0 & 1.2 & 1.2 \\
\hline - China & 0 & 2.4 & 0 & 0 & 0 \\
\hline
\end{tabular}

Referring to Table 3, migrant businessmen who originally came mainly from Indonesia and Thailand earn about RM1001 to RM5000, but there are also those who came from both countries to earn a total of RM5001 to RM10000 per month. Such income can also be obtained by those who came from India. It is found that most entrepreneurs who came from India have been working on food and grocery stores. This may also be linked to culture and foreign entrepreneurs themselves.

iii) Line of Business

To see whether working experience has been be a motivating factor for foreign entrepreneurs to venture into a certain line of business; we can refer to Table 4. It is study found that migrant entrepreneurs who choose to venture into clothing stores, salons and decorations, and food outlets on average, had similar experiences in their first job experience in Malaysia, where they worked as a sales assistant or factory workers and mechanics, tailors, or barber. This means that their working experiences have led them to do the same line of business. In addition, the opportunities available in these areas are certainly known by foreign businessmen because they had been in this business line as an observer. 
Table 4. Line of Business, Type of Jobs, Country of Origin, Type of Ownership and Income

\begin{tabular}{|c|c|c|c|c|c|c|c|c|c|c|c|}
\hline Line of Business & Hawkers $\mathrm{f}$ & food & Stall & $\begin{array}{l}\text { Furni- } \\
\text { ture }\end{array}$ & $\begin{array}{l}\text { Food } \\
\text { stall/ } \\
\text { restaurant }\end{array}$ & $\begin{array}{l}\text { Grocery } \\
\text { store }\end{array}$ & $\begin{array}{l}\text { Construction } \\
\text { /craftsman } \\
\text { house / boat/ } \\
\text { electric }\end{array}$ & $\begin{array}{l}\text { Clothes } \\
\text { shops/ } \\
\text { salon/ } \\
\text { decorative }\end{array}$ & $\begin{array}{l}\text { Electrical/ } \\
\text { building/ } \\
\text { agricultural } \\
\text { products }\end{array}$ & $\begin{array}{l}\text { Motor } \\
\text { vehicle } \\
\text { lworkshop }\end{array}$ & Other \\
\hline \multicolumn{12}{|l|}{ Types of Jobs } \\
\hline -Labor & 0 & 0 & 2.4 & 1.2 & 3.7 & 1.2 & 4.9 & 3.7 & 2.4 & 0 & 1.2 \\
\hline $\begin{array}{l}\text { - Assistant store / } \\
\text { factory }\end{array}$ & 2.4 & 1.2 & 7.3 & 7.3 & 17.1 & 7.3 & 0 & 19.5 & 1.2 & 0 & 0 \\
\hline - Maid / cleaner & 0 & 0 & 1.2 & 0 & 2.4 & 0 & 1.2 & 2.4 & 0 & 1.2 & 0 \\
\hline $\begin{array}{l}\text { - Mechanic / } \\
\text { Barber / Tailor }\end{array}$ & 0 & 0 & 0 & 0 & 0 & 0 & 0 & 7.3 & 0 & 0 & 0 \\
\hline \multicolumn{12}{|l|}{ Country of Origin } \\
\hline - Indonesia & 2.4 & 0 & 2.4 & 2.4 & 9.8 & 1.2 & 6.1 & 14.6 & 1.2 & 1.2 & 0 \\
\hline - Thailand & 0 & 0 & 8.5 & 2.4 & 11.0 & 1.2 & 0 & 6.1 & 1.2 & 0 & 0 \\
\hline - Myanmar & 0 & 0 & 0 & 0 & 0 & 0 & 0 & 3.7 & 0 & 0 & 0 \\
\hline -Kembodia & 0 & 0 & 0 & 0 & 0 & 1.2 & 0 & 1.2 & 0 & 0 & 1.2 \\
\hline - Filipina & 0 & 0 & 0 & 0 & 0 & 0 & 0 & 1.2 & 0 & 0 & 0 \\
\hline - Vietnam & 0 & 0 & 0 & 0 & 0 & 0 & 0 & 1.2 & 0 & 0 & 0 \\
\hline - Bangladesh & 0 & 0 & 0 & 2.4 & 0 & 2.4 & 0 & 0 & 0 & 0 & 0 \\
\hline - India & 0 & 0 & 0 & 0 & 2.4 & 2.4 & 0 & 0 & 0 & 0 & 0 \\
\hline - Pakistan & 0 & 0 & 0 & 1.2 & 0 & 0 & 0 & 1.2 & 1.2 & 0 & 0 \\
\hline -Lubnan & 0 & 1.2 & 0 & 0 & 0 & 0 & 0 & 1.2 & 0 & 0 & 0 \\
\hline - China & 0 & 0 & 0 & 0 & 0 & 0 & 0 & 2.4 & 0 & 0 & 0 \\
\hline \multicolumn{12}{|l|}{ Types of ownership: } \\
\hline -Sole ownership & 2.4 & 0 & 6.1 & 8.3 & 7.3 & 4.9 & 4.9 & 17.1 & 2.4 & 1.2 & 1.2 \\
\hline -Family Partnership & 0 & 1.2 & 1.2 & 0 & 14.6 & 1.2 & 1.2 & 9.8 & 1.2 & 0 & 0 \\
\hline $\begin{array}{r}\text {-Non-family } \\
\text { partnership }\end{array}$ & 0 & 0 & 3.7 & 0 & 1.2 & 2.4 & 0 & 6.1 & 0 & 0 & 0 \\
\hline \multicolumn{12}{|l|}{ Income (RM) } \\
\hline$-<1,000$ & 1.2 & 0 & 9.8 & 0 & 2.4 & 0 & 0 & 1.2 & 0 & 0 & 0 \\
\hline$-1,001-5,000$ & 1.2 & 0 & 1.2 & 3.7 & 14.6 & 4.9 & 2.4 & 25.6 & 2.4 & 1.2 & 0 \\
\hline$-5,001-10,000$ & 0 & 0 & 0 & 3.6 & 6.1 & 3.7 & 2.4 & 2.4 & 1.2 & 0 & 0 \\
\hline$-10,000-15,000$ & 0 & 0 & 0 & 0 & 0 & 0 & 0 & 3.7 & 0. & 0 & 1.2 \\
\hline$-15,000-20,000$ & 0 & 1.2 & 0 & 1.2 & 0 & 0 & 0 & 0 & 0 & 0 & 0 \\
\hline
\end{tabular}

Countries of origin of foreign entrepreneurs also play an important role in influencing the nature of their business because it involves the culture of a society. According to Table 4, respondents who came from Indonesia will focus on clothing stores, salons and decoration line of business while those originating from Thailand are concentrated in the restaurant business, which tomyam is known as one food that is synonymous with Thai society.

Many entrepreneurs of clothing stores, salons or decorations are actually a sole proprietorship. While for food shop, business ownership is more of a family partnership. There is an interesting scenario here where business ownership is particularly suited to the characteristics of the business itself. For example, for clothing, salons or decoration business, it can be done solely, but rather for food business, it needs manpower, then the ownership of the family partnership is ideal in this type of business. 
In terms of average monthly income, Table 4 shows that those who are in clothing stores, salons or decoration line of business has an average monthly income of about RM1001 to RM5000, as well as for those who are venturing in food business. Those who involve in field of construction or artisan houses or electricity, furniture shops and food vendors have a monthly income of up to RM 15,000 to RM20000. This line of business is very profitable and actually up to the expertise of the foreigners themselves. Thus, for foreign entrepreneurs who wish to obtain a higher monthly income, this is the areas of business that would certainly be the focus. However, if they only expect to live just enough to support family life, they will choose the area of business that do not require high costs such as clothing stores, salons or decoration.

To complete this framework, this study identified several motivating or driving factors such as working experience, qualifications, employer assistance, and encouragement from friends, and business opportunities. Table 5 shows the cross tabulation migrant business operators with these driving factors. Results shows that the majority of foreign entrepreneurs venture into business clothing stores, salons or decorations highlighted working experience factor (33\%), business opportunities (28\%) and encouragement $(24 \%)$ of friends as an impetus to them. Similarly, for those involved in the restaurant business.

Table 5. Business Line and Driving Factors

\begin{tabular}{lcccccc}
\hline Business Line & $\begin{array}{c}\text { Work } \\
\text { Experience }\end{array}$ & \multicolumn{2}{c}{$\begin{array}{c}\text { Education Employer's } \\
\text { Help }\end{array}$} & $\begin{array}{c}\text { Friend's } \\
\text { encouragement }\end{array}$ & Opportunities Total \\
\hline Hawkers & 1 & 0 & 0 & 1 & 1 & 3 \\
Food & 1 & 0 & 0 & 0 & 1 & 2 \\
Stall & 5 & 0 & 2 & 3 & 7 & 17 \\
Furniture & 4 & 1 & 0 & 4 & 6 & 15 \\
Food stall/restaurant & 15 & 0 & 0 & 11 & 8 & 34 \\
Grocery store & 4 & 0 & 0 & 5 & 3 & 12 \\
Construction/craftsmanhouse/boat/ & 5 & 1 & 0 & 1 & 2 & 9 \\
clothes shops/salon/decorative & 19 & 5 & 3 & 14 & 16 & 57 \\
Storeelectrical/building/agricultural & 3 & 1 & 0 & 3 & 0 & 7 \\
Motorvehicleworkshop & 1 & 0 & 0 & 1 & 0 & 2 \\
Others & 1 & 0 & 1 & 0 & 1 & 3 \\
TOTAL & 59 & 8 & 6 & 43 & 45 & 161 \\
\hline
\end{tabular}

Overall, the working experience factor has emerged as the main motivating factor to shift a foreign worker to become an entrepreneur in all areas of business except furniture shops and stalls in which these two business areas are highly motivated by the opportunity factor. The second motivating factor, after the working experiences are business opportunities, followed by encouragement from friends. The study also found that the help by employer and education play very little role as compared to other driving factors.

Figure 2 shows the framework for job displacement model of unskilled foreign workers to entrepreneurs in Malaysia. There are several circumstances that lead the immigrant entrepreneurs to immigrate to Malaysia. There are the pushing factors that make them leave their country of origin and the pulling factors that bring them to Malaysia.

While working as unskilled labour in Malaysia, there are two categories of factors: 1) driving factors and 2) internal or personal factors that affecting them to become entrepreneurs. Becoming an entrepreneur requires certain type of personal characteristics which are not possessed by everybody. Respondents are asked about the types of trait that they believe to be important for an entrepreneur and they consider only three, namely self-ability, eagerness to succeed and self-belief to become successful.

In terms of driving factors, this paper has identified five factors but the respondents only believe that the most significant factors are work experience, opportunities and encouragement from friends. 


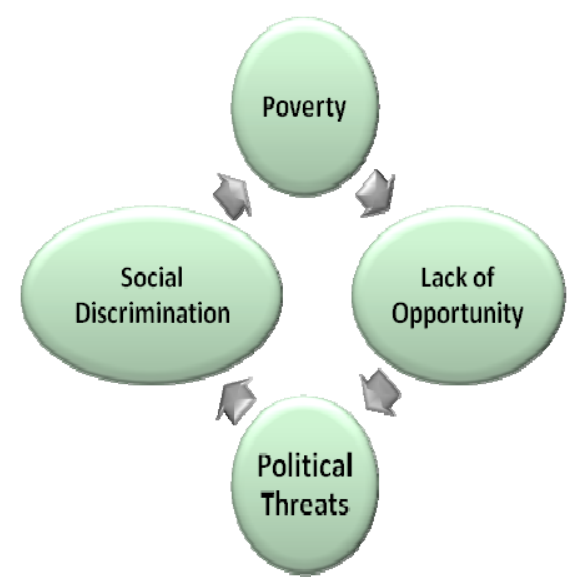

PUSH FACTOR

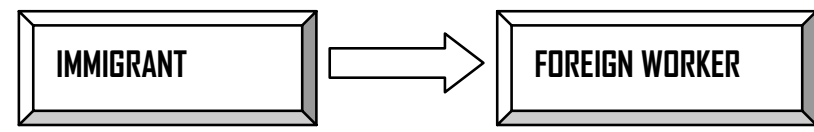

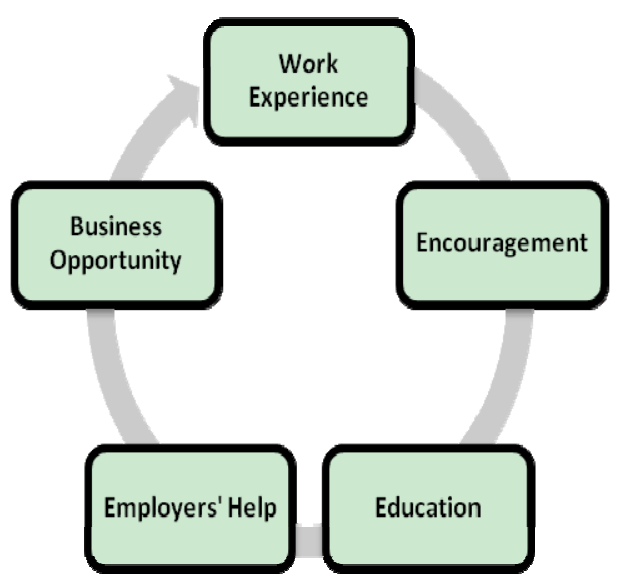

DRIVING FACTOR

\section{PULL FACTOR}

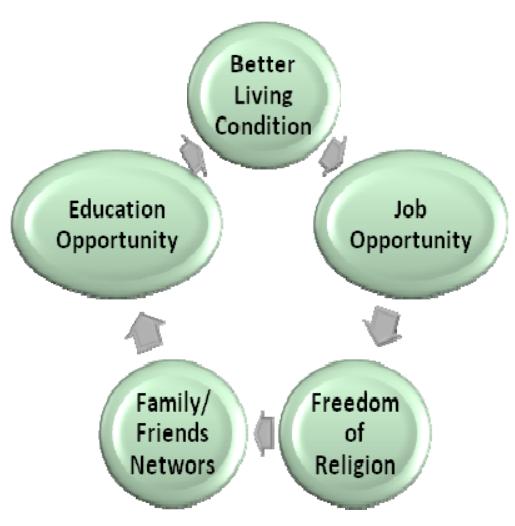

\section{INTERNAL/MOTIVATION FACTOR}

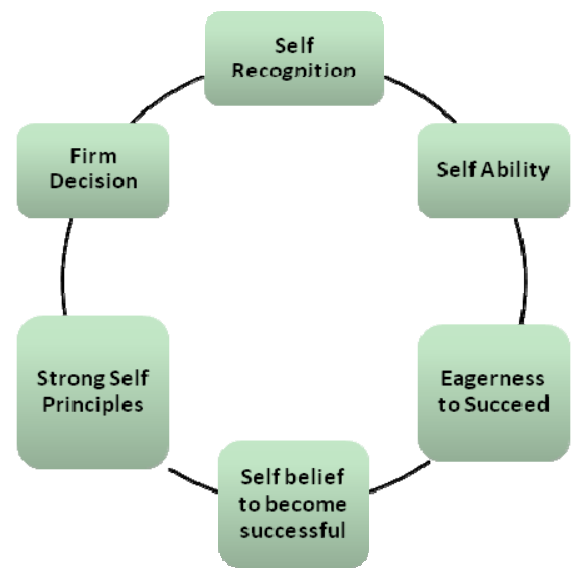

Figure 2. Framework of Job Displacement Model from Foreign Worker to Migrant Entrepreneur

\section{Conclusion}

To summarize, the study found that foreign businessmen who have become entrepreneurs in the period of 1 to 5 years are permanent residents, choose clothing business, salon or decoration and earns about RM1001 to RM5000 of monthly income. In terms of business line, many who choose the area of clothing, salon or decoration also has experience as a shop assistant and they come from Indonesia. Further, the types of business ownership are sole proprietorship.

In designing a framework of job displacement model from unskilled foreign labor to entrepreneurs, the study identified two categories of factors: driving factors and internal factors. The three main driving factors contributing to this shift are work experience, business opportunities, and encouragement of a friend.

\section{References}

Asan Ali Golam Hassan. (2009). Hipotesis Anjakan Pekerja Migran: Dari Buruh Kasar Kepada Pengusaha.

Prosiding Kebangsa an Ekonomi Malaysia ke IV. 
Ayda, E., Tuna, T., \& Jan, V. (2010). Diversity Matters: Immigrant Entrepreneurship and Contribution of Different Forms of Social Integration in Economic Performance of Cities. European Planning Cities. 18(4), 521-543. http://dx.doi.org/10.1080/09654311003593556

Baycan-Levent, T., \& Kundak, S. (2009). Motivation and driving forces of Turkish entrepreneurs in Switzerland. Innovation: The European Journal of Social Sciences, 22(3), 283-308.

Chrysostome, E., \& Lin, X. (2010). Immigrant entrepreneurship: Scrutinizing a p promising type of business venture. Thunderbird International Business Review, 52(2), 77-82. http://dx.doi.org/10.1002/tie.20315

Chrysostome, E. (2010). The success factors of necessity immigrant entrepreneurs: In search of a model. Thunderbird International Business Review, 52(2), 137-152. http://dx.doi.org/10.1002/tie.20320

Collins, J., \& Low, A. (2010). Asian female immigrant entrepreneurs in small and medium-sized businesses in Australia. Entrepreneurship \& Regional Development, 22(1), 97-111. http://dx.doi.org/10.1080/08985620903220553

Fairlie, R., \& Woodruff, C. M. (2010). Mexican-American Entrepreneurship. The B.E Journal of Economic Analysis \& Policy, 10(1), 1-42. http://dx.doi.org/10.1787/9789264095830-en

Hernan, R., \& Pierrette, H. S. (2009). Mexican Immigrant Gardeners: Entrepreneurs or ExploitedWorkers? Social Problems, 56(1), 70-88. http://dx.doi.org/10.1525/sp.2009.56.1.70

Mediha, S., Nijkamp, P., \& Rietdijk, M. (2009). Cultural diversity and urban innovativeness: personal and business characteristics of urban migrant entrepreneurs. Innovation: The European Journal of Social Sciences, 22(3), 251-281.

Mustafa, M., \& Chen, S. (2010). The strength of family networks in transnational immigrant entrepreneurship. Thunderbird International Business Review, 52(2), 97-106. http://dx.doi.org/10.1002/tie.20317

Miri, L., \& Yeoshua, H. (1996). New Entrepreneurs and Entrepreneurial Aspirations among Immigrants from the Former U.S.S.R in Israel. Journal of Business Research, 36, 59-65. http://dx.doi.org/10.1016/0148-2963(95)00163-8

Stephan, R. (2008). When skilled and unskilled labor are mobile: a new economic geography Approach. University of Passau. 